\title{
The Catholic Worker Movement and Racial Justice: A Precarious Relationship
}

\author{
LINCOLN RICE \\ Marquette University
}

The Catholic Worker Movement, widely known for its critique of violence and capitalism in American culture, has largely neglected racism. This seems surprising because its urban houses of hospitality, staffed mostly by middle-class whites, provide material resources disproportionately to impoverished African Americans. The movement's embodiment as a white movement and the failure of its founders (Dorothy Day and Peter Maurin) to prioritize racial justice has impeded its ability to adequately confront racism. This article contrasts the ways in which racism was addressed by the founders with the way it was addressed by two prominent African American Catholic Workers. The article includes a new Catholic Worker narrative to explain the movement's relationship with racial justice and offer suggestions for ways the movement can mine its own rich resources to become an authentically anti-racist movement.

Keywords: Catholic Worker, Dorothy Day, Peter Maurin, Arthur Falls, racism, Helen Riley

A $\mathrm{T}$ the opening home game for the Minnesota Twins in April 2016, twenty-five white Catholic Workers blocked a light-rail line near the baseball stadium for ninety minutes. They were all arrested, "gently processed and released in less than two hours." ${ }^{1}$ This group of Catholic Workers from all over the Midwest United States was collaborating with Black Lives Matter Minneapolis and the Black Liberation Project. They were responding to the recent killing of a local black man by the Minneapolis

${ }^{1}$ Brenna Cussen Anglada, 'In 'Followership,' Catholic Workers Take Action for Black Lives Matter," National Catholic Reporter, June 4, 2016, https://www.ncronline.org/news/ people/creative-disruption-followership-catholic-workers-take-action-black-lives-matter.

Lincoln Rice has taught at the University of Wisconsin-Milwaukee and Marquette University. Fordham is publishing his critical edition of Peter Maurin's Easy Essays in spring 2020. He earned his PhD in moral theology at Marquette University in 2013 and is a member of the Milwaukee Catholic Worker. 
police and the horrifying reality that 100 percent of the people killed by the Minneapolis Police Department during the previous ten years had black or brown skin. After the widely publicized killing of Michael Brown in Ferguson, Missouri, by a police officer in August 2014, Midwestern Catholic Workers realized that the Catholic Worker Movement had not adequately addressed the issue of racism in the United States. ${ }^{2}$ The Minneapolis action was unique in that Catholic Workers have rarely been arrested for the cause of racial justice, in contrast to countless arrests to protest war and various military actions. The Minneapolis action indicates a renewed commitment on the part of Catholic Workers to engage racism in a more deliberate manner.

The Catholic Worker Movement is known primarily for its houses of hospitality, soup kitchens, voluntary poverty, and strong pacifist stance. The movement was founded by Dorothy Day (1897-1980) and Peter Maurin (1877-1949) when they published the first issue of the Catholic Worker newspaper on May Day 1933. Maurin was born and raised on a simple farm in rural France; Day was raised in Chicago and had grandparents who fought on opposite sides during the Civil War. In December 1933, Day opened the first house of hospitality for housing the homeless. During the 1930s, dozens of other houses of hospitality were started all over the United States by folks who had visited the New York house or read about its exploits in the newspaper. Today there are more than 150 Catholic Worker communities in the United States and a handful in other countries.

If one opens Mel Piehl's 1982 history of the Catholic Worker, Breaking Bread, ${ }^{3}$ and scours the index for the words race, African American, or black, one will not find anything. The same thing occurs if one opens Nancy Roberts' Dorothy Day and the Catholic Worker (1984), Rosalie Reigle's Dorothy Day: Portraits by Those Who Knew Her (2003), and Dan McKanan's The Catholic Worker after Dorothy (2008). ${ }^{4}$ The problem is not with these books, which are definitive sources for the history of the Catholic Workerthe problem is the Catholic Worker Movement. There are minor exceptions to this phenomenon. William Miller's index for A Harsh and Dreadful Love (1973) lists two instances under the index heading "racial injustice." The first instance briefly noted the involvement in the early Catholic Worker of

2 Ibid.

${ }^{3}$ Mel Piehl, Breaking Bread: The Catholic Worker and the Origin of Catholic Radicalism in America (Philadelphia: Temple University Press, 1982).

${ }^{4}$ Nancy L. Roberts, Dorothy Day and the Catholic Worker (Albany, NY: State University of New York Press, 1984); Rosalie G. Riegle, Dorothy Day: Portraits by Those Who Knew Her (Maryknoll, NY: Orbis Books, 2003); Dan McKanan, The Catholic Worker after Dorothy (Collegeville, MN: Liturgical Press, 2008). 
the white Jesuit priest and racial justice advocate, John LaFarge. The second recognized instances of the Catholic Worker addressing racial injustice during the 1930s. Both instances will be explored in greater depth in the following pages. ${ }^{5}$ Rosalie Riegle's oral history of the movement, Voices from the Catholic Worker, also contains two instances under the heading "racism." The first is part of her interview with the black Catholic Worker Arthur Falls, who will have his own section below. The second relates how the St. Elizabeth Catholic Worker found an abandoned building to use that was owned by a black Catholic parish in Chicago. ${ }^{6}$ Despite these minor exceptions, one can attempt this experiment with any number of books on the Catholic Worker and find little or no reference to African Americans or racism. Even though the founders of the Catholic Worker Movement, Dorothy Day and Peter Maurin, categorically condemned racism during their lifetimes, confronting white supremacy has not been a critical component of the Catholic Worker Movement.

To measure the importance of racial justice in the Catholic Worker Movement, Figure 1, below, maps the frequency of articles per issue of the New York Catholic Worker newspaper that dedicated significant space to racism against African Americans. Significant space indicates at least a couple of sentences. It is not enough if racism is only mentioned along with a list of other evils. Though it may seem counterintuitive, the greatest frequency of articles occurred in the 1930s, during the first four years of the New York Catholic Worker. In 1935, the newspaper averaged more than three articles every issue with significant space dedicated to racism. Even in 1964 when the Civil Rights Act was passed and in 1968 when Martin Luther King Jr. was assassinated, racism was less frequently addressed, with an average of about two articles per paper. This chart also documents increased frequency on articles about anti-black racism in the last three years, with each issue of the paper averaging 2.4 articles in 2018. The purpose of the illustration is not to shame the New York Catholic Worker. My examination of other Catholic Worker communities with long publication histories reveals that the New York community is representative of the movement as a whole on the issue of racism. ${ }^{7}$

At this point, it will be helpful to define five terms: race, racism, anti-black racism, anti-racism, and racial liberalism. Bryan Massingale has noted that

${ }^{5}$ William D. Miller, A Harsh and Dreadful Love (New York: Liveright, 1973), 69, 79-81.

${ }^{6}$ Rosalie Riegle Troester, Voices from the Catholic Worker (Philadelphia: Temple University Press, 1993), 26-28, 51-52.

7 I created the graph and measured the frequency of articles dedicated to racism by carefully looking at every article in the newspaper. 


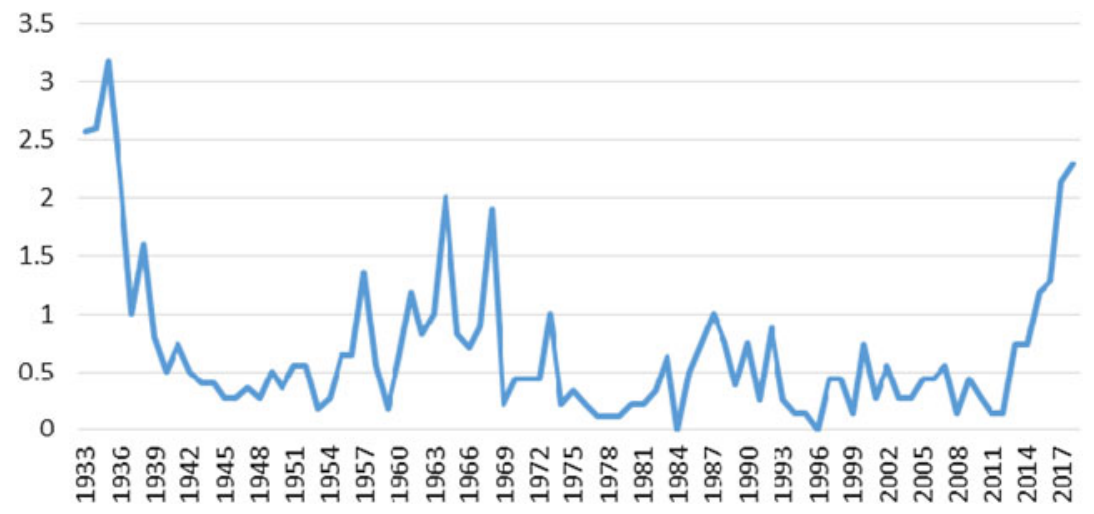

Figure 1. Frequency of articles per issue of the New York Catholic Worker dedicated to anti-black racism.

race is a "troublesome term." ${ }^{8}$ Race has "limited scientific usefulness" and speaks more to a cultural, social, and political reality. ${ }^{9}$ I will employ the definition of racism from the Midwest Catholic Worker open letter on racism (2017), which was the fruit of a collaborative effort by white Catholic Workers to define racism: "Racism is a cultural phenomenon that creates institutionalized patterns of discrimination against people of color so as to consolidate and bestow power and privilege to white people." ${ }^{10}$ It is important to note that white people benefit from this phenomenon whether or not they acknowledge it. Anti-black racism is a term that focuses specifically on racism that harms African Americans. When racism is mentioned in this article, it will primarily be referring to the racism experienced by African Americans. The history, stereotypes, and discrimination faced by each non-white group in the United States is unique, and it exceeds the scope of this article to thoroughly address racism faced by other groups. Racism can be, and often is, inadvertently perpetuated. Anti-racism refers to intentional acts to create a culture in which institutionalized patterns of discrimination against people of color are deemed unacceptable and rectified. This last point may be further clarified by defining racial liberalism, which describes a mind-set that does not tolerate "overt bigotry," but leaves institutional or structural forms of racism largely unaddressed. This viewpoint underestimates the

${ }^{8}$ Bryan N. Massingale, Racial Justice and the Catholic Church (Maryknoll, NY: Orbis Books, 2010), 3 .

${ }^{9}$ Ibid. Italics in the original.

${ }^{10}$ Midwest Catholic Worker Faith and Resistance Gathering 2017, "Lament. Repent. Repair.: An Open Letter on Racism to the Catholic Worker Movement," Catholic Worker Anti-Racism Review, spring 2018, 2-4, at 2. 
"advantages and privileges that have accumulated in the white population because of the past history of discrimination," believing that the elimination of overt discrimination alone is an adequate response to racism without any need for restorative policies. ${ }^{11}$ Though these terms are defined by their twenty-first-century usage, their clarity and precision will aid us in recognizing the strengths and shortcomings of racial justice work during the midtwentieth century.

To more thoroughly explore the Catholic Worker Movement and racial justice, the first section of this article will begin by examining the racial justice praxis of the movement's founders, Dorothy Day and Peter Maurin. Though they both condemned racism, they also suffered from racial liberalism. Anti-racism was not essential to their praxis and neither constructed a theology of racial justice steeped in black sources. The second section will document two seminal black Catholic Workers, Arthur Falls and Helen Riley, who each incorporated their experience as African Americans into their Catholic Worker framework to embody a passionate critique of America's culture of racism. The last section will incorporate earlier information to propose a new Catholic Worker narrative to explain the movement's relationship to racial justice. The conclusion will offer suggestions for ways the Catholic Worker Movement can mine its own rich resources to become an authentically anti-racist movement.

\section{The Founders: Dorothy Day and Peter Maurin}

When the Catholic Worker first began in New York City, its editorial offices and the first house of hospitality were in a neighborhood populated by Irish, German, and Italian immigrants along with their descendants. Though African Americans did not live in the neighborhood, the paper covered the discrimination against blacks from the very first issue. The articles on racism explored poor wages, lack of overtime pay, the Scottsboro case, the denial of voting rights, racial prejudice by white Catholics, segregation, slavery, and lynchings. ${ }^{12}$

${ }^{11}$ The definition of racial liberalism is adapted from Charles W. Mills, Black Rights/White Wrongs (New York: Oxford University Press, 2017), 158-59, 203; and Nils Gilman, "End of an Era: The Collapse of Racial Liberalism," American Interest 13, no. 5 (2018), https:// www.the-american-interest.com/2018/03/02/collapse-racial-liberalism.

12 "Negro Labor on Levees Exploited by U.S. War Dept.," New York Catholic Worker, May 1933, 1-2; "Communists, Despite Noise, Are Not Only Defender of Scottsboro Case," New York Catholic Worker, May 1933, 1, 6; "Is the Problem Black or White?" New York Catholic Worker, May 1933, 3; Dorothy Day, “On Pilgrimage," New York 
Some of the early houses of hospitality, which were autonomous from the New York house, faced severe consequences for aiding African Americans. The Baltimore Catholic Worker, which was staffed by white workers, offered shelter to African Americans fleeing terrible conditions in the South. Ultimately, the house was closed by the city for being a public nuisance, with Day explaining that the city closed it because it was unacceptable in Baltimore to have whites and blacks "together under one roof." ${ }^{13}$ Before the house was closed, the white male staff members "were arrested and thrown in jail over night and accused of running a disorderly house."14 There was also an early house in Houma, Louisiana, which was started by Father Jerome Drolet, an associate pastor at a local parish. He provided hospitality for anyone who was homeless and built a ballpark where "interracial teams" competed. The pastor of the parish disapproved and Drolet was soon transferred, which resulted in the discontinuation of the work. ${ }^{15}$

To their credit, both Day and Maurin spoke out against racism more than most of their white Catholic contemporaries. Although they both condemned racism, we should be wary of holding them up as contemporary role models for anti-racism. By today's standards, their example bordered on paternalism, and they failed to capitalize on the insights of black writers and activists.

The most prominent white American Catholic for the cause of racial justice during the first half of the twentieth century was the Jesuit John LaFarge (1880-1963). He was a regular visitor to the New York Catholic Worker during the 1930s and offered clarifications of thought on racism. During the 1930s, he also presided over the National Catholic Federation for the Promotion of Better Race Relations and its publication, the Interracial Review. Unfortunately, his orchestrated takeover of the Federation from its lay black leadership was the reason he was in charge of the group and its publication. Despite his many published works on racial justice, he suffered from a paternalistic attitude that "helped create a vacuum of black leadership in the church." 16 This attitude was most obvious in his 1960 book on race relations, where he wrote: "although the

Catholic Worker, February 1971, http://www.catholicworker.org/dorothyday/articles/ 933.pdf.

13 Day, "On Pilgrimage," February 1971.

14 Dorothy Day, "Letter on Hospices," New York Catholic Worker, January 1948, http:// www.catholicworker.org/dorothyday/articles/183.pdf.

15 Day, "On Pilgrimage," February 1971.

16 David Southern, John LaFarge and the Limits of Catholic Interracialism (Baton Rouge: Louisiana State University, 1996), 361; Lincoln Rice, Healing the Racial Divide (Eugene, OR: Pickwick Publications, 2014), 1-3. 
Negro is the victim of discrimination, he does not necessarily know the answer or the cure." 17

For the purposes of this article, I will offer four measurements for white activists to employ to protect their writings against paternalism and the ignoring of black insights: (1) regular references to racism, (2) employing and dialoguing with black sources, (3) including racism in one's central texts, and (4) integrating the insights of racial justice into other affected topics such as poverty and labor conditions. Although there is the danger of placing unreasonable twenty-first-century standards on white Catholics from the midtwentieth century, these standards were already illustrated in the work of the black sociologist W. E. B. Du Bois in the early twentieth century. In The Souls of Black Folk (1903), Du Bois was forthright in proclaiming, "The problem of the twentieth century is the problem of the color-line." ${ }^{18}$ Each essay in the book begins with a "haunting echo" of black slave songs to modern readers. In addition, Du Bois highlighted the impact that anti-black racism has had on American economics, industrialization, greed, poverty, and the merchant class. ${ }^{19}$ During the third year of the Catholic Worker, Du Bois published Black Reconstruction in America (1935), in which he related the integral and positive influence that African Americans played in Reconstruction after the Civil War. This work corrected the racial bias in the previous histories of white historians, who blamed the failure of Reconstruction on "Negro ignorance and corruption." 20 The remainder of this section will provide highlights of Maurin's and Day's interaction with racial justice, followed by a critique.

The basic ideas of the movement are grounded in the thought of cofounder Peter Maurin. Because Maurin died in 1949 and his mind had begun failing beforehand, his writing corpus is more limited than Day's. Nevertheless, he did address racism and provided a sample size large enough to offer a justified critique. One year after the founding of the movement in May 1934, Maurin, along with a Protestant friend, Herman Hergenhan, moved into a Harlem storefront at 2070 Seventh Avenue that had been offered for use to the Catholic Worker. Although the storefront housed a few men, it was not primarily a house of hospitality, but an evangelization center from which to spread the message of the Catholic program on

${ }^{17}$ John LaFarge, The Catholic Viewpoint on Race Relations, rev. ed. (Garden City, NY: Hanover House, 1960), 71-73.

${ }^{18}$ W. E. B. Du Bois, The Souls of Black Folk, 3rd ed. (Chicago: A. C. McClurg \& Co., 1903), 13.

19 Ibid., 92-98, 148-49, 164-65, 169, 250.

${ }^{20}$ W. E. B. Du Bois, Black Reconstruction in America (New York: Antheneum, 1992 [1935]), 713 . 
social and racial justice to African Americans. Maurin was aware that many prominent black intellectuals had embraced communism during the $1920 \mathrm{~s}$ and 1930s. Although Maurin agreed with the communist critique of capitalism as oppressive, he presented an alternative solution of a village economy based on Catholic principles. He embraced a distributist economic system, in which private property was dispersed among the population as widely as possible. ${ }^{21}$ The storefront sponsored a program almost every evening, including talks on the Catholic Worker program, Catholic apologetics, catechism, art classes with Ade Bethune, and even French classes. Speakers included priests and lay people, with the lay people being both black and white. ${ }^{22}$

At first, the storefront seemed successful, but after the first summer it never attracted more than a small crowd. Though the Catholic Worker made both black and white friends at the storefront, Maurin's friend, Herman Hergenhan, reported:

Some were doubtful of the usefulness of the work; others were convinced that it was just wasted effort. Teaching a few small children a few small things, they reasoned, would not remove the stench of race discrimination; handing out a few free copies of The Catholic Worker would not, they held, convince an oppressed people of the efficacy of Catholic Worker philosophy. ${ }^{23}$

The storefront was closed in the latter half of 1935 when the owner, Paul Daley, an attorney and member of the National Guard, discovered the nonviolent tendencies of the Catholic Worker. ${ }^{24}$ In the end, the outreach of the Harlem storefront, although commendable, was in no way a center for confronting or organizing against racism. ${ }^{25}$

21 Peter Maurin, “I Agree," New York Catholic Worker, September 1934, 6.

22 "Harlem Program," New York Catholic Worker, October 1934, 1.

${ }^{23}$ Herman Hergenhan, “C. W. Sympathizers Protect Quarters in Harlem Riot," New York Catholic Worker, April 1935, 1, 6, at 1.

24 Arthur Sheehan, Peter Maurin: Gay Believer (Garden City, NY: Hanover Press, 1959), 115-17; Marc H. Ellis, Peter Maurin (New York: Paulist Press, 1981), 82-86; Marc H. Ellis, "Peter Maurin: To Bring to Social Order to Christ," in Revolution of the Heart, ed. Patrick G. Coy (Philadelphia: Temple University Press, 1988), 15-46, at 31-35.

25 During this same period, the New York Catholic Worker dedicated financial resources in a creative manner to support the organizing efforts of white laborers. In October 1936, the New York house supported a group of striking seamen by renting an additional storefront near the strikers' headquarters to provide food and respite. The ancestral make-up of the seamen was largely Irish, Italian, Polish, Hungarian, and Slavic. Dorothy Day, Long Loneliness (New York: Harper and Row, 1952), 208-09; James T. Fisher, On the Irish 
Maurin communicated his thought through Easy Essays, which were short writings in the form of poemlike stanzas. The first essay that Maurin dedicated to racism against African Americans was published in a collection of essays in the May 1938 issue of the New York Catholic Worker entitled "The Race Problem." He stated that white people have not solved the "Negro problem" and "It is up to Negroes to find the right solution." He asserted that instead of trying "to force themselves on white people or to imitate white people ... [blacks should act] the way Saint Augustine wants white people to behave."26 Regarding Maurin's understanding of Augustine, Maurin composed one essay in which he quoted Augustine's phrase, "Love God and do what you please." 27 In essence, if black people were a paragon of love, other races that felt superior would begin to admire and follow the example of African Americans. Again, Maurin believed that if blacks behaved in the loving way white people should behave, whites would be inspired to change their behavior based on the "power of example." 28

In a 1941 arrangement of essays entitled "Let's Be Fair to the Negroes for Christ's Sake," Maurin began with a scientific argument to state that no race is superior to another and continued with a theological argument that all races "were created by the same Creator and redeemed by the same Redeemer." He also argued that all races partake in the same Eucharist, will share the same heaven, and are part of the same mystical body of Christ. Noting that white and black bishops share the same faculties through ordination, he concluded by again asserting that whites would admire blacks if they followed the example of Saint Augustine. In this instance, he also mentioned that Saint Augustine was a bishop in Northern Africa, probably to illustrate a common continental heritage between American blacks and Augustine that Maurin hoped would win African Americans to his viewpoint. ${ }^{29}$ Luke

Waterfront (Ithaca, NY: Cornell University, 2010 [2009]), 75-77; Kate Hennessy, Dorothy Day: The World Will Be Saved by Beauty (New York: Scribner, 2017), 91-93.

${ }^{26}$ Peter Maurin, "The Race Problem," New York Catholic Worker, May 1938, 1, 8.

${ }^{27}$ Peter Maurin, "St. Augustine," New York Catholic Worker, October 1941, 7; Augustine, Homilies on the First Epistle of John, Homily 7, paragraph 8. The original Latin omits the word God, which is included by Maurin and many others who quote the sentence: "Dilige, et quod vis fac." The Latin text is from the nineteenth-century Patrologia Latina edition of Augustine's writings, published by Jacques-Paul Migne. The work is available for free online by the publishers of Città Nuova at www.augustinus.it/latino/ index.htm. The Latin title for Augustine's homily is In Epistolam Ioannis ad Parthos Tractatus Decem and can be found here: www.augustinus.it/latino/commento_lsg/ omelia_07_testo.htm.

${ }^{28}$ Ibid.

29 Peter Maurin, "Let's Be Fair to the Negroes for Christ's Sake," New York Catholic Worker, September 1941, 1, 8. 
Stocking notes another example of Maurin using a group's ancestry to win them over with his many Irish-focused essays, which presented a view of history intended to convert to his line of thought the Irish-American audience present in New York and Boston. ${ }^{30}$

This represents the extent of Maurin's analysis of racial justice regarding African Americans. Most of his essays focused on the need for religion to inform public discourse and the forging of a distributist economy based on charity and voluntary poverty. Totally absent was an integration of racism into his framework. On the few occasions when he wrote on racism, most of which focused on anti-Semitism, it was extrinsic to his broader framework.

In March 1934, Dorothy Day wrote about a recent visit with the editor of Opportunity: A Journal of Negro Life, a publication of the National Urban League, which played a pivotal role during the 1920 for the Harlem Renaissance. Day told then-editor Elmer Anderson Carter that the New York Catholic Worker was "not only for the white, but the negro." She hoped to have black writers covering "not only on race problems but on social justice in general." She shared with him the story of a young white child who did not see color and that her goal was for the New York Catholic Worker to become "not a paper for black or white, but for the Catholic Worker." ${ }^{31}$ Day did not perceive that raising a white child to be colorblind only increases the probability that a child will grow up to be ignorant of racial discrimination and more likely to find such behavior acceptable. ${ }^{32}$ Although the early writings of Day demonstrated an awareness and concern for the injustices faced by blacks in America, she did not author many articles on the topic. Most of the articles written about racial justice in the early New York Catholic Worker newspaper were penned by others. When Day did write on racism, her writing betrayed the notion that racism was only one among many social justices instead of a constitutive part of social injustice in the United States.

In early 1943, during World War II, Day traveled through Florida and Alabama to examine the conditions of African Americans. In Birmingham, she talked to an elderly woman who had been a slave as a child. She told Day how she had to lie across the foot of her owner's bed to keep the feet

3o Luke Stocking, "When the Irish Were Irish: Peter Maurin and the Green Revolution" (MA thesis, University of St. Michael's College, 2006), 124, 140, 147-48.

${ }^{31}$ Dorothy Day, "Day by Day," New York Catholic Worker, March 1934, http://www. catholicworker.org/dorothyday/articles/311.pdf.

${ }^{32}$ For a recent study that confirms that color-blindness leads to racial discrimination becoming more acceptable to children, see Evan P. Apfelbaum, Kristin Pauker, Samuel R. Sommers, and Nalini Ambady, "In Blind Pursuit of Racial Equality," Psychological Science 21 (2010): 1587-92. 
of the owner and his wife warm. In addition to documenting the poor living conditions, meager wages, and lack of ownership among African Americans, she related the attitude of many Southern whites toward her presence. She was often told, "We always take care of our $n-\mathrm{s}$... We know how to treat them and we want the northerners out of here." 33

In August 1955, Emmett Till, a fourteen-year-old African American boy from Chicago, was lynched in Mississippi for allegedly whistling at a white female storekeeper. The publicity raised from an open-casket funeral his mother organized in Chicago incited black outrage against racial injustices in the South and galvanized support for the Montgomery Bus Boycott four months later. In October 1956, not long after the Till lynching and during the Montgomery Bus Boycott, Day visited Memphis and Mississippi on what she referred to as a "pilgrimage," aware that she was visiting the area where Till was murdered. She documented the formation of white citizen councils all over the South to reinforce segregation and white supremacy in response to the black resistance inspired by Till and the Montgomery Bus Boycott. Speaking of the fear present among many whites, she wrote: "The exploiter has always been afraid, as the guilty has always been afraid, afraid of those whom he has starved and ill treated." Documenting low wages, inadequate education, and horrific violence against African Americans, she asserted that whites had "come to deny God in his brother, the Negro." 34

In April 1957, Day visited the Koinonia Farm, an interracial community in Americus, Georgia. The community began quietly in 1942, but faced economic and physical harm after it became better known. Day visited the community for two weeks to help with planting and other chores. Because of the interracial nature of the community, the farm had difficulty obtaining seed. On entering a local store to obtain seed on their behalf, Day was called a "n-r-lover" and "a northern Communist whore." 35 The community took turns each night keeping watch by sitting in a car on the side of a road that

${ }^{33}$ Dorothy Day, "Day after Day," New York Catholic Worker, March 1943, http://www. catholicworker.org/dorothyday/articles/387.pdf. She also wrote about this trip in Dorothy Day, "Aims and Purposes," New York Catholic Worker, May 1943, http:// www.catholicworker.org/dorothyday/articles/919.pdf. I have chosen to alter the n-word in most cases at the request of the journal editors. However, I have not done so when quoting Helen C. Riley at the end of the essay, because I do not believe a white scholar has the right to alter the way an African American writer uses the term.

${ }^{34}$ Dorothy Day, “On Pilgrimage," New York Catholic Worker, November 1956, http://www. catholicworker.org/dorothyday/articles/714.pdf. During this trip, she also visited Montgomery and reported on the bus boycott.

${ }^{35}$ Dorothy Day, "Fear in Our Time," New York Catholic Worker, April 1968, http://www. catholicworker.org/dorothyday/articles/253.pdf. 
ran through the community's farm. One evening, as Day sat in the car with another woman, an unknown car came down the road with its headlights off and repeatedly shot at her car. Remarkably, no was injured. Regarding her time there, Day commented, "We did learn something of what mob hatred is like. And I must say that it makes your blood run cold. Not many of us ever experienced this kind of venomous hatred." 36

Day initially intended that the articles she wrote during this latest trip to the South would be a chapter in her 1963 book, Loaves and Fishes, which focused on the first thirty years of the Catholic Worker Movement. In the original manuscript, her visit to the Koinonia Farm was the pinnacle of a chapter entitled "The Negro and the Land of Cotton." As an interracial back-to-theland venture that placed exceptional value on racial equality, the communal sharing of property, and dedication to pacifism, Day believed that this community would have been Maurin's vision for the South. ${ }^{37}$

In August 1961, Day received her initial feedback on the Loaves and Fishes manuscript that she had submitted to its future publisher, Harper and Row. Two blind reviewers provided negative feedback on her visit to the South. One reader stated that she "invades the South" and there "is considerable social commentary in this chapter, much of which is bitter." The other reader wrote that the chapter should be cut. ${ }^{38}$ The chapter was removed from the manuscript shortly afterward.

Unfortunately, neither her 1952 autobiography, The Long Loneliness, nor Loaves and Fishes engaged racism against African Americans. These two books highlight what Day viewed as most integral to the movementpoverty and nonviolence. These two books were, and continue to be, the vehicles for indoctrinating many into the Catholic Worker Movement. Their omission of race has likely contributed to further omissions on the topic of racism by those who admire or participate in the movement.

Despite the omission of racism in those two books, Day continued to write about racism in her newspaper column during the 1960s. As she was fond of equating the suffering of the poor with the suffering of Christ, she spoke of "the sufferings of the Negro, in whom Christ is crucified over and over

36 Ibid.

37 Day, Loaves and Fishes, original manuscript, 239-45, Dorothy Day-Catholic Worker Collection, Marquette University Archives, Milwaukee, WI, Series D-3, Box 3, Folder: Loaves and Fishes, Editorial Papers, 1960-1963. Hereafter, this collection will be referred to as DDCW.

${ }^{38}$ Blind reader comments, DDCW, Series D-3, Box 3, Folder: Loaves and Fishes, Editorial Papers, 1960-1963. 
again." She believed this situation required "direct action," such as including African Americans in commerce and as recipients of the works of mercy. ${ }^{39}$

In early 1965, Day was in Mississippi during the Selma marches, which hoped to gain voting rights for African Americans in the South. The US Commission on Civil Rights was also conducting hearings there to ascertain the extent to which the liberties of black citizens had been trampled. The African Americans who spoke to the commission were endangering their own lives and many required an escort home. Day attended one of the hearings, "overcome with horror and shame at the tale of brutality that unfolded. Kidnappings and beatings, eyes gouged out, dismembered corpses found in bayous." 40 Despite this, she still openly criticized the political focus of Stokely Carmichael and the Civil Rights movement. Displaying her strong anarchist and anti-state beliefs, she averred that more would have already been accomplished to combat racism if resources were instead utilized for creating financial and societal infrastructure for African Americans. ${ }^{41}$ This thought ignores history, which is replete with examples of successful black entrepreneurs being intimidated, lynched, or having their businesses destroyed. The worst instance of this was the Tulsa Race Riot of 1921, which resulted in whites burning down thirty-five square blocks in the successful black area of the city and killing approximately 300 African Americans. ${ }^{42}$ Black financial and societal infrastructure provided scant resistance to white supremacy in the United States.

In 1968, Day was "stunned" by the assassination of Dr. Martin Luther King Jr. The day after the assassination was Good Friday, the day commemorating the execution of Christ, in which he "shed His blood." Day portrayed King in starkly christological terms: King's "blood poured out, shed for whites and blacks alike." 43 She continued:

39 Dorothy Day, “On Pilgrimage," New York Catholic Worker, September 1964, http://www. catholicworker.org/dorothyday/articles/818.pdf.

40 Dorothy Day, "On Pilgrimage," New York Catholic Worker, March 1965, http://www. catholicworker.org/dorothyday/articles/823.pdf.

${ }^{41}$ Dorothy Day, “On Pilgrimage," New York Catholic Worker, June 1966, http://www. catholicworker.org/dorothyday/articles/840.pdf. Day's focus on financial and social infrastructure while eschewing political change was reminiscent of Booker $\mathrm{T}$. Washington's, though their reasons differed. Washington chose this route because he did not think political change was practical in the South while Day abstained from political solutions because she was an anarchist.

${ }^{42}$ For a useful source on the riot, see The Tulsa Race Riot: A Report by the Oklahoma Commission to Study the Tulsa Race Riot of 1921 (Oklahoma City: Oklahoma Commission to Study the Tulsa Race Riot of 1921, 2001).

${ }^{43}$ Dorothy Day, "On Pilgrimage," New York Catholic Worker, April 1968, http://www. catholicworker.org/dorothyday/articles/252.pdf. 
Martin Luther King died daily, as St. Paul said. He faced death daily, and said a number of times that he knew he would be killed for the faith that was in him. The faith that men could live together as brothers. The faith in the Gospel teaching of non-violence. The faith that man is capable of change, of growth, of growing in love. ${ }^{44}$

At the end of 1968, Day was continuing her own education of African American history. In her column, she stated that she was reading NAACP cofounder W. E. B. Du Bois's The Soul of Black Folk, which she recommended as "a good beginning in the study of African and American history in relation to slavery past and present." 45 In 1970, Day reflected that it was "only these last years that we begin to realize how much we have studied all the histories save the histories of Africa and her peoples, and how little we have learned of the minorities in our own country." 46 Although the Catholic Worker Movement had highlighted the violence and abuse faced by African Americans since the first issue of the New York Catholic Worker, it was only after the death of King that Day took a greater interest in African American history.

In November 1969, Day spoke at St. Francis College (now University) in Loretto, Pennsylvania. Her talk included a discussion of racism, which was uncommon during her public speaking engagements. The audience believed her allegations of racism in America to be false:

The audience at the college was a bit belligerent over some of the points I made about interracial justice. They could overlook my pacifism, they expect that of a woman, but my assertions that there was hostility when a Black moved into a white neighborhood, and that white people were harassed and intimidated if there was any possibility of their selling to a black buyer, met with vehement denials. There was no discrimination and the Blacks could buy into any neighborhood they wanted, several members of the audience asserted, and with hostility. ${ }^{47}$

In 1971, reflecting on how little had changed regarding racism in America, Day wrote:

44 Ibid.

45 Dorothy Day, “On Pilgrimage," New York Catholic Worker, December 1968, http://www. catholicworker.org/dorothyday/articles/891.html. Robert Coles, Dorothy Day: A Radical Devotion (Reading, MA: Addison-Wesley Publishing, 1987), 22.

46 Dorothy Day, “On Pilgrimage," New York Catholic Worker, March-April 1970, http:// www.catholicworker.org/dorothyday/articles/499.pdf.

47 Dorothy Day, “On Pilgrimage," New York Catholic Worker, December 1969, http://www. catholicworker.org/dorothyday/articles/905.pdf. 
The past looks unutterably horrible with its lynchings and the tale has been told again and again of blacks burned alive, dragged behind cars through the street, castrated and hung, fingers cut off and kept as souvenirs, stories to match the horrors of Vietnam and Brazil today ... I remember the black who ran a little cleaning establishment who was locked in his shop which was sprinkled with gasoline and set afire a few years ago. It took him a few days to die. And how many black students and slum youth shot to death this last year! ${ }^{48}$

Day plainly admitted that she saw no simple or forthcoming solution to address the problem of racism in the United States. ${ }^{49}$ This is in stark contrast to her statement only a few years previous in 1966 that black liberation movements would accomplish more in combating racism by focusing on financial and societal infrastructure. Day wrote very little on race after this 1971 article.

Unfortunately, neither Day nor Maurin wrote or worked adequately against anti-black racism. They rarely wrote on it and it was not part of their central texts. Except for a few instances in the late 1960s, Day neither utilized black sources nor integrated the insights of racial justice into her discussions of related injustices such as war and poverty. For most of her life, Day did not realize how entrenched racism was in American culture. Her later writings illustrate a greater understanding of the pervasiveness of white superiority and prejudice. She was not blind to the issue and even took multiple trips into the Deep South to document some of racism's most atrocious manifestations, but she never placed the issue at the forefront of her writings. Similarly, Peter Maurin was expressly against racism and set out religious and scientific reasons against racial superiority, but his work against antiblack racism was also lacking. Anti-black racism constituted a minor part of his writings and he underestimated its entrenchment in American culture. He wrongly believed racism could be solved by moral suasion and model behavior on the part of African Americans. Essentially, their stance on racism was more closely allied with the colorblind mentality of racial liberalism than with anti-racism.

\section{The Black Catholic Worker Experience: Arthur Falls and Helen Riley}

This section will briefly examine the lives of two prominent black Catholic Workers, Arthur Falls (1901-2000) and Helen Riley (1926-2013).

${ }^{48}$ Day, "On Pilgrimage," February 1971.

49 Dorothy Day, Duty of Delight: The Diaries of Dorothy Day, ed. Robert Ellsberg (Milwaukee: Marquette University Press, 2008), 485. 
Their experiences as African Americans distinctly informed their appropriation of the Catholic Worker vision. Falls was involved with the movement during the 1930 s and early 1940 s in the North while Riley was involved with the movement from the late 1940s through the mid-1950s in the South, though she was also an associate editor for the New York newspaper during the 1960s.

\section{Arthur Falls}

Arthur Falls was a black Catholic physician who founded the first Catholic Worker in Chicago in 1936. He was born in Chicago in 1900 to parents who had emigrated from the South. His father was a convert to Catholicism, but his mother descended from a long line of Creole Catholics. He grew up in racially mixed Chicago neighborhoods and his family belonged to Our Lady of Solace Catholic Church, which was a white parish. Because of his race, he was not permitted to attend the parish's school. He could have gone to the Catholic school of the "colored parish," but his parents knew that that school was inferior and chose to send him to public schools. ${ }^{50}$ In 1925, he graduated from Northwestern University Medical School and shortly afterward became involved with the Chicago Urban League and the Federated Colored Catholics. Reflecting on the racism he faced in the Catholic Church as a child and an adult, he stated, "It is very fortunate that I was born into the Roman Catholic Church because under no stretch of [the] imagination could I conceive that I ever voluntarily would have joined it." ${ }_{51}$

As noted earlier, almost every issue of the early New York Catholic Worker featured multiple articles on racism against African Americans. In October 1933, five months into its publication, Falls was given a copy of the newspaper and was enamored that a Catholic publication focused so much of its coverage on racial justice. One month later, he wrote the New York Catholic Worker to suggest that it change its masthead to feature a black worker and a white worker instead of two white workers. The December 1933 issue of the paper reflected this suggestion, and a black worker has been a feature of the paper's masthead ever since. ${ }^{52}$

Falls was not interested in founding a house of hospitality. After garnering enough local support, he started a Catholic Worker school in fall 1936. He

50 Arthur G. Falls, "Reminiscence, 1962," Catholic Social Action Collection, Marquette University Archives, Box 1, Folder 1, p. 7; Box 1, Folder 12, disc 18-2, pp. 4-5. Hereafter, this collection will be referred to as AGF.

51 AGF, Box 1, Folder 2, pp. 69-70; AGF, Box 1, Folder 10, pp. 506-07.

52 Falls to Day, November 3, 1933, DDCW, Series 2-2, Box 1, Folder 11. 
argued that the best way to improve the situation of the poor and African Americans in Chicago was through organized clarifications of thought followed by action. He organized different working groups, which focused on the areas of race, labor, liturgy, and cooperatives. Each week one of the groups would host a public forum on their topic. The Catholic Worker excited Falls because it provided him with a vehicle for bringing black and white people together in Chicago. Previously, he had unsuccessfully tried to integrate the Chicago chapter of the Federated Colored Catholics, which remained an almost completely African American group. ${ }^{53}$

One aspect of the Catholic faith that particularly attracted him, as it did others in the Catholic Worker Movement, was the doctrine of the mystical body of Christ. Per this doctrine, all are connected as members or potential members of Christ's body and have a responsibility for one another. For Falls, the logical implication was that those Catholics who actively or passively worked to trap African Americans in the ghetto were followers of a heresy he termed the "mythical body of Christ." The mythical body of Christ excluded non-whites as members or potential members of the body of Christ and promoted the delusion that white people were the normative measure of the Catholic faith. ${ }^{54}$

Even though the Chicago group was very active and attracted a diverse group of people, Dorothy Day was unhappy that they had not started a house of hospitality. After a visit to Chicago in May 1937, two young white men accompanied Day to the bus depot. Before boarding the bus she insisted that they start a house of hospitality. She did this without consultation with the rest of the Chicago group and even went so far as handing them a set of keys to an apartment that she had commandeered. Falls did not try to prevent the opening of the hospitality house on Blue Island Avenue, but he believed that it detracted from the amount of good they could accomplish in Chicago. ${ }^{55}$

The Catholic Worker school and house of hospitality in Chicago closed with the beginning of Word War II in 1942. Nevertheless, many of those involved with Falls at the Chicago Catholic Worker school, such as John Cogley and Ed Marciniak, would stay committed to anti-racism work even after they left the Catholic Worker movement. Falls continued to organize

${ }^{53}$ Falls to Priest, May 5, 1936, DDCW, Series W-2.1, Box 3, Folder 1; Arthur G. Falls, "Chicago Letter," New York Catholic Worker, November 1936, 5.

${ }^{54}$ Arthur G. Falls, "Restrictive Covenants," Chicago Catholic Worker, March 1941, 1-3.

55 AGF, Box 1, Folder 14, disc 23-1, p. 8; Francis Sicius, World Made Flesh (Lanham, MD: University Press of America, 1990, 36-39); John Cogley, Canterbury Tale (New York: Seabury Press, 1976), 8-14. 
for racial justice and played a pivotal role in desegregating Chicago area hospitals in the early $19605 .{ }^{56}$

Francis Sicius, whose dissertation focused on the Chicago Catholic Worker, asserted a fissure in thought regarding racism for Dorothy Day and Arthur Falls: "Falls protested racism and prejudice because it prevented the enbourgeoisement of blacks, whereas Dorothy Day, antibourgeois to the core, viewed racism and prejudice as axioms to the capitalist 'laws' of competition and supply and demand." 57 This is obviously an oversimplification, but it does provide a helpful starting point for examining the differences between Day and Falls. Falls was committed to addressing racism as a pervasive evil that permeated American society and served as a direct assault on the doctrine of the mystical body of Christ. Though Falls was not as radical as Day regarding economics and pacifism, he was an ardent supporter of the cooperative movement in Chicago and refused requests to serve in a medical capacity in the military during World War II. Day, though she obviously rejected the oppression caused by racism, did not ascertain its entrenchment in American society. Speaking at a fiftieth-anniversary celebration of the Catholic Worker in Chicago in 1986, Falls stated, "We didn't have a house of hospitality established, but we did a lot more." ${ }_{58}$

\section{Helen Riley}

Helen Riley, an African American convert to Catholicism, founded Blessed Martin House of Hospitality at 299 South Fourth Street in Memphis. It remained in operation from 1952 to 1956. The house provided hospitality for children of working mothers who could not afford daycare. Many of the mothers picked cotton and were driven by truck to Arkansas or Mississippi to work for the day. Before Dorothy Day visited Memphis on one occasion, Riley warned her, "You'll be breaking the law by staying over night in the same house with a Negro. A communist would be arrested for it." Day was not arrested for visiting and was very impressed with the work being done. ${ }^{59}$

${ }^{56}$ Robert G. Morris Jr., MD, et al. v. Chicago Hospital Council, et al., 61 C232, US District Court, 1819-1999, civil case files, 1938-1985, Record Group 21, National Archives Building, Chicago; National Medical Association, "Chicago Court Agreement Reached," Journal of the National Medical Association 53 (March 1961) 205-06.

57 Francis Sicius, “The Chicago Catholic Worker," in Revolution of the Heart, ed. Patrick G. Coy (Philadelphia: Temple University Press, 1988), 337-59, at 339.

58 Arthur G. Falls, Chicago Catholic Worker 5oth Anniversary Celebration, December 5, 1986, cassette, DDCW, Series W-9.1, Box C-27.

59 Dorothy Day, “On Pilgrimage," New York Catholic Worker, November 1952, http://www. catholicworker.org/dorothyday/articles/640.pdf; Day, “On Pilgrimage,” April 1968. 
In 1947, eighteen-year-old nursing student Helen Riley, who at the time went by the last name Day, was studying for her nursing degree in New York City. She was introduced to the Catholic Worker Movement through Father Francis Meenan, who was teaching her the Catholic faith as she prepared to enter the Catholic Church. She was impressed with the Catholic Worker vision of racial equality, but disdained its adherence to voluntary poverty. She was raised in poverty in the South, though Riley's father taught at a small college. She enjoyed volunteering at the New York Catholic Worker and noted, "Race seemed to matter not at all, and ordinary people like myself were living and working together in order to grow in grace and in love of God in each other, and in love of the Church, her liturgy and sacraments."6o

Riley soon embraced the entire philosophy of the Catholic Worker Movement, including its voluntary poverty and pacifism. She decided to open a house of hospitality in Memphis. ${ }^{61}$ In 1950, with a white Catholic named Bill Slavick, she approached Father J. Coyne to moderate a new group that would meet to discuss Catholic Worker thought. Father Coyne, whose Josephite Order was founded to serve African Americans, was the only priest in the area who would agree to moderate their group. The group did not want race to be their primary focus, but something that would rise organically from conversations as they discussed other societal problems. They discovered that their Southern setting and the interracial makeup of the group resulted in racism manifesting itself in every issue no matter what topic or action was proposed. ${ }^{62}$ The group discussed Catholic Worker philosophy, matters of social and racial justice, and Pope Pius XII's 1943 encyclical on the mystical body of Christ, Mystici Corporis Christi. Though the group was not in total agreement, Riley opened Blessed Martin House with the blessing of the local bishop on January 6, 1952. ${ }^{63}$ In addition to offering daycare, the house also provided an after-school program for neighborhood kids. Though the children could be of any race, they were

Caldwell noted that a white pastor had been "jailed and fined" for staying with a black friend not long before. Helen Caldwell Day, Not Without Tears (New York: Sheed and Ward, 1954), 137.

${ }^{60}$ Day, Not Without Tears, 1-3.

${ }^{61}$ Day, Not Without Tears, 3-4, 27, 181.

62 Day, Not Without Tears, 11-12. In her book, Day referred to Slavick as Jim to protect his identity. Clare Hanrahan, Looking Things Over-Again: Memphis Catholic Workers in the 1950s and the Blessed Martin House of Hospitality, 2nd ed. (Asheville, NC: Celtic Woodcraft, 2006), 20-22.

${ }^{63}$ Day, Not Without Tears, 14, 100-115, 131; Hanrahan, Looking Things Over-Again, 2225, 30-31. The first house was located at 299 S. Fourth Street. In early 1953, it moved to $218 \mathrm{~S}$. Turley, in the rear of the property. The local bishop who supported the opening of the house was William L. Adrian. 
almost exclusively African American. Helen and her son, Butch, who was about four years old when the house began, were the only live-in volunteers. She only wanted "that Butch should grow up as well-adjusted, friendly, full of charity." And she believed "that the things Butch would gain by the experience of growing up in the house ... outweigh anything he might lose by it." They did not run the house by themselves; they received help from both black and white members of the Catholic Worker group and requested that the working mothers help out one day a week. ${ }^{64}$

Though Riley regularly quoted Dorothy Day and Peter Maurin, her views regarding race were distinctive. She was very critical of the enforced segregation in Catholic churches, especially in the South. She attended the white Catholic church, which was closer to her home because, "I don't admit the existence of two Catholic Churches established by God, one White and one Colored: but I believe in one Holy, Catholic and Apostolic Church ... let us not divide Christ; that is to crucify him all over again." 65 Her strong and well-reasoned theological opinions poignantly displayed the harm caused by racial divisions in the Catholic Church.

Writing on the mystical body of Christ, Riley stated, "we could not compromise, as Our Lord would not compromise but died for all, and lived for all, and loves us all as members of His Mystical body. We were incidentally interracial in one sense, but necessarily so in another, to show our belief in the universal character of the Church." ${ }^{66}$ Broadly writing about the solution to racial injustice, she argued, "we can't change the situation by getting mad or becoming bitter. We can only change it by love. But it must be a love that is all embracing." 67

On September 17, 1955, Helen married Jessie Riley and the house of hospitality closed shortly afterward, on June 1, 1956. ${ }^{68}$ The newlyweds moved to Barstow, California, where she worked as a children's librarian for thirty-eight years. Though no longer part of a house of hospitality, she served as an associate editor for the New York paper from June 1963 to November 1970. Her most notable contribution during this time was a prayer in the June 1963 issue of the paper entitled, “A Black Man's Prayer.” This prayer emphasized the stark reality of racism, took pride in being black, and urged love as a tool against hatred. It is included at the end of this article. ${ }^{69}$

64 Day, Not Without Tears, 3-4, 131-34; Hanrahan, Looking Things Over-Again, 32-37.

65 Day, Not Without Tears, 53-54.

66 Ibid., 97.

67 Ibid., 57.

68 Hanrahan, Looking Things Over-Again, 51-52.

69 Helen C. Riley, “A Black Man's Prayer,” New York Catholic Worker, October 1963, 5. Obituary on Legacy.com, http://www.legacy.com/obituaries/desertdispatch/obituary. aspx?pid $=168640708$. 
Both Falls and Riley adapted the Catholic Worker to address racism in the North and South, respectively. Their inescapable African American identity led them to appropriate the Catholic Worker in very distinct ways in comparison to most of their white counterparts. Falls believed that a Catholic Worker school was the best way to organize opposition to racism while Riley risked arrest for organizing an interracial group to provide hospitality. In both instances, their passion for confronting racial justice and their willingness to be informed by their black experience was evident. Falls and Riley transcended the racial liberalism of their white Catholic counterparts and took on an anti-racist perspective, in which they assessed how anti-black racism had seeped into almost every aspect of American culture and worked to transform the culture. Unlike the lives of Maurin and Day, no one can authentically relate the stories of Falls and Riley without including how they organized resistance to racial injustice.

\section{A New Catholic Worker Narrative}

This section will propose a new narrative to explain the relationship of the Catholic Worker Movement with racial justice. To begin, during the $1930 \mathrm{~s}$ there was more diversity regarding people and thought in the Catholic Worker Movement. The early movement included individuals passionate about agrarianism, arts and crafts, liturgical renewal, unionism, cooperatives, sociology, and racial justice. Although Day wrote about pacifism early on, pacifism was simply one of the Catholic Worker's many trademarks. Therefore, Falls' not being a pacifist did not make him unique among Catholic Workers during the 1930s. At this early period in the Catholic Worker Movement, it contained not only racial liberals, but some anti-racists. Multiple houses in the movement were confronting and suffering consequences for addressing racism. And in addition to the New York paper's regular publishing of articles on racism, it also reprinted articles by black writers, often editorials and news items from black publications. ${ }^{70}$ These actions provide evidence that some in the early movement listened to African American voices and displayed a willingness to suffer for confronting racism.

During and after World War II, the movement was on the defensive for its pacifist stance, and it was during this time that pacifism became a defining

${ }^{70}$ For example, see NAACP News Service, "Minister Run Out of Ala. for Supporting NRA Code for Race," New York Catholic Worker, October 1933, 3; NAACP News Service, "To Attack Low Salaries for Negro Teachers," New York Catholic Worker, October 1933, 8; Editor, Interracial Review, "The Encyclicals and the Negro," New York Catholic Worker, May 1936, 3. 
trademark of the movement. The movement began to attract more pacifists and became less attractive to non-pacifists, who might otherwise have been attracted to other aspects of the movement. This led to a greater expectation that those in the movement would adhere to its pacifist stance, which explains why Riley's involvement in the movement included an acceptance of pacifism in contrast to Falls.

Like the rest of white America, Catholic Worker interest in racial justice after World War II coincided with key historical events: the Montgomery Bus Boycott, the months leading up to the passage of the Civil Rights Act of 1964, and the assassination of Martin Luther King Jr. Like the rest of white America, Catholic Worker interest in racial justice was minimal after the assassination of King in 1968. Like much of white America, the Catholic Worker Movement adopted a racial liberal viewpoint, in which only overt acts of racism were noticed and confronted. There have been a few shining examples of anti-racist commitment during this era, including the Open Door Community in Atlanta. Founded after the death of Dorothy Day in 1981 by four white Presbyterians who grew up in the South in the 1960s, they were deeply troubled by the racism they witnessed from white Christians during that decade. ${ }^{71}$ They have made dismantling racism one of their primary missions. The primary metaphor that defines their vision for community is Martin Luther King Jr.'s Beloved Community, which challenges the types of exclusion that are normative in society, including race, class, gender, and sexuality. ${ }^{72}$ Nevertheless, the Open Door Community is an exception in the post-World War II Catholic Worker Movement.

With many in white America, the Catholic Worker Movement began to reexamine racism with increased awareness and urgency after the killings of African American teenagers Trayvon Martin and Michael Brown in 2012 and 2014, respectively. In other words, the killings of Trayvon Martin and Michael Brown awakened many white Catholic Workers-as well as many whites in the rest of American culture-to the necessity of transcending racial liberalism and taking on an anti-racist perspective. For example, Karen House in St. Louis, Missouri, has published a twenty-four-page booklet called The Roundtable on timely topics up to four times a year since 1978. From 1978 to 2011 , only one issue focused on racism, though a couple of other issues featured an article addressing racism. Since 2012, three issues have focused solely on racism and substantial parts of other

${ }^{71}$ Peter R. Gathje, Sharing the Bread of Life: Hospitality and Resistance at the Open Door Community (Atlanta: Open Door Community, 2006), 9-11, 17, 38, 64-66, 157. In early 2017, the Open Door Community relocated to Baltimore.

72 Gathje, Sharing the Bread of Life, 9-11, 38, 157. 
issues have confronted white supremacy. The winter 2014 issue featured articles written by people involved in the protests in Ferguson, most of whom were people of color who did not have any direct connection to the Catholic Worker Movement. This mirrors the New York Catholic Worker newspaper's practice of reprinting articles on racism by African American writers and black publications during the early $1930 .^{73}$

The protest at the Twins game mentioned at the beginning of the article was one of the Faith and Resistance Retreats that a group of Midwest Catholic Workers have been organizing since 2003. These yearly retreats typically dedicate a weekend each spring to learn more about a problem and to raise public awareness by risking arrest. The choice of venue each year is decided by the group and demonstrates what they view as the most important contemporary issues in need of being addressed. Out of fifteen retreats, nine have focused on military issues, two have focused on the environment, one focused on immigration, and three have focused on racism against African Americans. It was the three from 2015 to 2017 that focused on racism, as Midwest Catholic Workers became cognizant of the continuing evil of racism after the killing of Michael Brown. ${ }^{74}$

Though houses of hospitality and pacifism are still the hallmarks of the Catholic Worker Movement, the diversity of the movement today is matched only by the movement in the 1930s. For example, Catholic Worker farmer Eric Anglada notes a significant increase in Catholic Worker farms over the last decade, as well as many houses of hospitality growing some of their own food as a way to offer meals that are healthier than what is normally donated. ${ }^{75}$ In other words, even though World War II decimated the diversity of the Catholic Worker Movement, its original diversity is beginning to flourish again, which includes listening to and including the voices of African Americans. Unfortunately, it is outside the scope of this article to explore further examples of increasing diversity in the movement today.

\section{Conclusion}

The lack of critical analysis regarding race is particularly glaring when one considers that the Catholic Worker's urban houses of hospitality are

${ }^{73}$ Copies of The Roundtable can be found at http://newsite.karenhousecw.org/aboutkaren-house/the-round-table.

${ }^{74}$ Frank Cordaro, email message to author, October 7, 1017.

${ }^{75}$ Eric Anglada, “Taking Root," America, May 6, 2013, http://www.americamagazine.org/ issue/taking-root. 
staffed almost completely by white people while the homeless guests staying at the houses are disproportionately black. Though the movement has proved to be fertile ground for a robust theology of nonviolence, voluntary poverty, and anarchism, it has failed to augment these areas by incorporating a meaningful theology of racial justice, which is critical to understanding violence, poverty, and authoritarianism in the United States.

Although some in the Catholic Worker Movement have taken concrete steps to address racism in the wake of the deaths of Trayvon Martin and Michael Brown, the movement has lacked adequate engagement against anti-black racism for most of its history. Though Maurin and Day are representative of the best response to racism offered by white Catholics during their lifetimes, they did not provide examples of how to confront white supremacy in a meaningful way. There are Catholic Worker precedents in Falls and Riley for lives passionately dedicated to anti-racism. Both played a prophetic role for the movement with their words and actions. Because racism can adapt itself to new situations, Falls and Riley must not serve as examples to be copied, but as sources of inspiration for creative confrontation. Additionally, W. E. B. Du Bois offered a sterling historical example of how a racial critique could be successfully integrated into an appraisal of poverty, violence, and authoritarianism in America.

Despite its shortcomings on racial justice, five aspects inherent to the Catholic Worker Movement can be utilized toward it becoming an antiracism movement. First, many urban Catholic Worker communities have regular interactions with African American guests who come looking for help. These guests could provide a rich resource for investigating current and concrete examples of racism, and how racism has been a contributing factor in American poverty. Of course, care must be taken to recognize the power dynamic that exists between those with resources and those in need. Mechanisms, such as exit interviews, could be helpful not only in discerning systems of racial injustice in local communities, but also unintentional practices of racism within the Catholic Worker. Second, the writings of Dorothy Day and many Catholic Workers emphasize the presence of Jesus in the poor. The movement would benefit from extending this doctrine to include the black Jesus as portrayed in the writings of black liberation theologians such as James Cone. As mentioned previously, Day compared King's assassination to the crucifixion of Christ, but focused more on King's faith in nonviolence. A more explicit connection between black suffering and the crucifixion of Christ could provide the Catholic Worker with a deeper emotional, prayerful, and theological encounter with white supremacy. Third, Peter Maurin employed a specific Irish narrative to instill pride in Irish Americans and attract them to his 
viewpoint. ${ }^{76}$ As previously stated, Maurin also provided the example of the African Saint Augustine when addressing African Americans in an Easy Essay. The Catholic Worker could extend this tradition by researching and sharing the lives of African Americans who share facets of the Catholic Worker vision. This intentional practice would bring a greater knowledge of African American history to Catholic Workers and open the door for authentic dialogue between black sources and Catholic Worker social theory. Fourth, the Catholic Worker has used much of its intellectual power in forming a critique of militarism and violence. Expanding this critique to include patterns of abuse by police, especially toward African Americans, would be a logical extension of the Catholic Worker's pacifist stance. Lastly, the Catholic Worker has always possessed a strong critique of capitalism as a structural evil. Augmenting this thought with a robust structural understanding of white supremacy that moves beyond anecdotes would strengthen its intellectual attack on capitalism by illuminating the role of racism in American capitalism. The incorporation of these proposals into the Catholic Worker Movement would provide a method for it to move beyond an inadequate racial liberal engagement with racism toward authentically building what Peter Maurin referred to as a "functional society." 77

\section{A Black Man's Prayer by Helen C. Riley}

Our Father:

You call all men sons-help us to see and recognize our son-ship and our brotherhood.

Apartheid-nigger ${ }^{78}$-jim crow-white man's burden-all those expressions which we use to express feelings of superiority-of separateness and hatelet them have no place upon our lips nor in our hearts. Help us, instead, to know and understand that there are no strangers here-just sons and brothers.

Have regard, O Lord and see how we, your black children, have been denied and disinherited by our fairer brothers-as if we were bastard children, to be explained, to be apologized for, to be kept hidden and out of sight, to be exploited-blamed-despised.

${ }^{76}$ Stocking, "When the Irish Were Irish," 124-48.

77 Peter Maurin, “A Radical Change," New York Catholic Worker, October 1934, 1.

${ }^{78}$ Although I have altered previous occurrences of the n-word in this article at the request of the editors, I have retained Helen C. Riley's use of it in this prayer because I do not believe a white scholar has the right to alter the way an African American scholar uses the term. 
Help us to see in our own sufferings, a pale reflection of your sufferings, and so, unite our own to Yours. Give us the will and strength and courage to fight mightily for justice-yet meanwhile to endure injustice patiently and with charity toward those who make us suffer most-let us not fight hatred with hatred, but hatred with love.

Let us understand that in us you are crucified again across our nation and the world-and let others see and understand this too.

Our little children, Lord who are barred from schools because they are black-or who worse still are mocked and ridiculed and spat upon because they are not barred from schools-help us to see Who really suffers in them: "Whatever you have done to these-you have done to Me."

Lest I should come to despise and hate myself for being black-or come to resent and hate all others for not being black, remind me of these things often, that I may worthily and becomingly call you: Father.

Amen 79

79 Riley, “A Black Man's Prayer,” reprinted with permission of The Catholic Worker. 